\title{
一技術報告一
}

自動還元特性を利用した簡便なジクワットとパラコートの吸光測定法

西田憲市，成原政治，堤 一博，伊東晋治

大分県警察本部科学捜查研究所

干870-8502 大分県大分市大手町3-1-1

\section{A Simple Colorimetric Determination of Diquat and Paraquat Utilizing Automatic Reduction Property}

\author{
Kenichi Nishida, Masaharu Narihara, Kazuhiro Thuthumi and Sinji Ito \\ Forensic Science Laboratory, Oita Prefectural Police H. $Q$. \\ 3-1-1 Otemachi, Oita-shi, Oita, 870-8502, Japan
}

(Received 25 November 2003; accepted 17 March 2004)

\begin{abstract}
We developed a simple colorimetric method which can separately determine paraquat and diquat utilizing automatic reduction property of diquat under existence of tetramethylammonium hydroxide. In the first step, diquat in the sample was automatically reduced by adding tetramethylammonium hydroxide, and UV/VIS spectrum $\left(\lambda_{\max }=430 \mathrm{~nm}\right)$ and absorbance at $430 \mathrm{~nm}$ were measured for confirmation and determination of diquat. In the second step, paraquat in the sample was also reduced by adding sodium hydrosulfite, and UV/VIS spectrum $\left(\lambda_{\max }=396 \mathrm{~nm}\right.$, $600 \mathrm{~nm}$.) and absorbance at $600 \mathrm{~nm}$ were measured for confirmation and determination of paraquat. The calibration curves were linear in the concentration range from 1-100 ppm for both compounds. The herbicide containing both paraquat and diquat, Preeglox $-\mathrm{L}^{\circledR}$, showed typical UV/VIS spectra of each compound, and there was a good correlation between herbicide concentration and paraquat and diquat concentrations. The established method was successfully applied to forensic samples, gastric content and heeltap solution.
\end{abstract}

Key words: Paraquat, Diquat, Automatic reduction, Colorimetric method

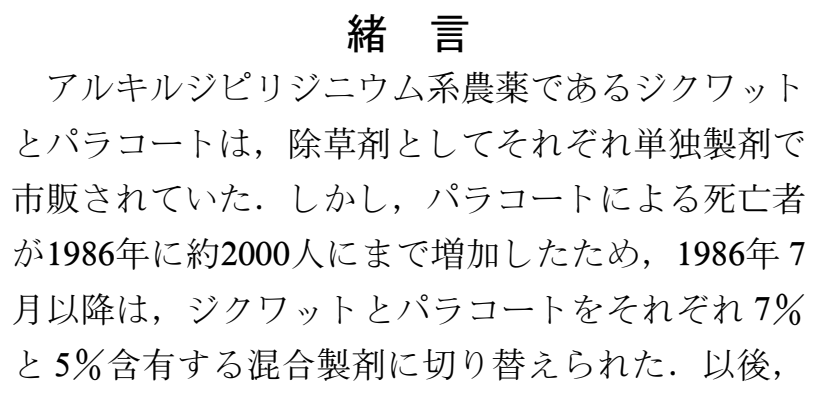

徐々に死亡者は減少していったが，現在でも依然高 い水準で推移している11)。た，旧製品であるパラ コート単独製剤による死亡事例は, 製剤変更から 17 年経過した今でも全くなくなってはいない。これら 農薬の簡便な確認法は，1\%ハイドロサルファイト ナトリウム $-1 \mathrm{~N}$ 水酸化ナトリウムによる呈色法 $\left(\mathrm{Na}_{2} \mathrm{~S}_{2} \mathrm{O}_{4}-\mathrm{NaOH}\right.$ 法 $)$ がある.この呈色法は, アル 
カリ性下 1 電子還元したパラコートが $\lambda_{\max }$ に396 $\mathrm{nm}$ と $600 \mathrm{~nm}$ を持つ青色を, ジクワットが $\lambda_{\max }$ に $379 \mathrm{~nm}$ と430 nm を持つ黄緑色を呈することによる が，この呈色法では， ジクワットの $\lambda_{\max }=430 \mathrm{~nm}$ でのモル吸光係数 $\varepsilon$ が5000に対してパラコートの $\lambda_{\text {max }}=396 \mathrm{~nm}$ での $\varepsilon$ が 45000 とあまりにも強いた め, ジクワットの吸収を確認できない欠点を持って おり，自殺などで使用された農薬製剤が，混合製剂 なのかパラコート単独製剤なのかの識別ができなか った．そのため, $\mathrm{Na}_{2} \mathrm{~S}_{2} \mathrm{O}_{4}-\mathrm{NaOH}$ 法を改良した二 次微分 ${ }^{2}$ や二波長分光分析 ${ }^{3)}$ やジクワットをアルカ リ性下加熱して分解させる方法4)などの報告がある が，混合製剂を証明するためには，高速液体クロマ トグラフィ5)やキャピラリー電気泳動(6)などの分離 分析に頼らざるを得なかった.

ジクワットまたはパラコートは, その含量が多い と自動還元によって青色または黄緑色を呈すること は知られていた7)。これらの自動還元は，4 級アン モニウムイオンが関与していると推定して, 我々は 同じ 4 級アンモニウムイオンを持つ水酸化テトラメ チルアンモニウムをジクワットとパラコートの混合 溶液中に添加してみたところ，ジクワットのみが自 動還元され，溶液が黄緑色を呈する $\left(\lambda_{\max }=430 \mathrm{~nm}\right)$ ことを発見した．そこで，この特性とハイドロサル ファイトナトリウムによる還元を組み合わせること により，混合溶液中でもジクワットとパラコートを それぞれ独立して測定できる方法を開発し，これを 混合製剂であるプリグロックス $\mathrm{L}^{\circledR} の$ 分析に応用し た.

\section{1 試薬類}

\section{材料および方法}

ジクワットジブロミドとパラコートジクロリド は，ICI ジャパンLTD（東京）から供与を受けた ものを使用した。ハイドロサルファイトナトリウム は，和光純薬工業株式会社（大阪）の化学用を用い た. 水酸化テトラメチルアンモニウムは, ナカライ テスク株式会社（京都）の五水和物を使って50\%水 溶液を調製し，これを $5^{\circ} \mathrm{C} て ゙$ 保存したものを使用し た. 分光光度計は, 島津製作所 UV-8600を使用し た。
混合製剤は，プリグロックス $\mathrm{L}^{\circledR}($ ゼネカ株式会 社, 東京, パラコートジクロリド $5.0 \%$, ジクワッ トジブロミド7.0\%含有）を用いた。

胃液及び吐物は，上記混合製剂を服用して中毒死 した70歳代男性のものを使用した。

\section{2 操作法}

セミミクロセルに試料 $0.3 \mathrm{ml}$ を入れ， $50 \%$ 水酸化 テトラメチルアンモニウム水溶液 $0.2 \mathrm{ml}$ 加えて分光 光度計内で20分間放置した後, ジクワットの確認の ためスペクトル測定あるいは $430 \mathrm{~nm}$ での吸光度を 測定した。 その後，ハイドロサルファイトナトリウ ムを約 $2 \mathrm{mg}$ 添加して混和後, 直ちにパラコート確 認のためスペクトル測定あるいは $600 \mathrm{~nm}$ での吸光 度を測定した。

\section{結果および考察}

水酸化テトラメチルアンモニウムのジクワットお よびパラコートへの影響を調べるために，まず， 50 ppmのジクワットとパラコートの混合標準液に対 して各種濃度の水酸化テトラメチルアンモニウムを 添加して，操作法に従って吸光度を測定した．Fig. 1.に示すと打り, ジクワットに対しては水酸化テ トラメチルアンモニウム濃度が $10 \%$ まで吸光度が定 量的に上がっていき，それ以後徐々に平衡化してい った. パラコートに対しては, 水酸化テトラメチル アンモニウム濃度の増加により吸光度が低下する傾 向が見られた。つぎに同じ試料を使い，10\%〜25\%

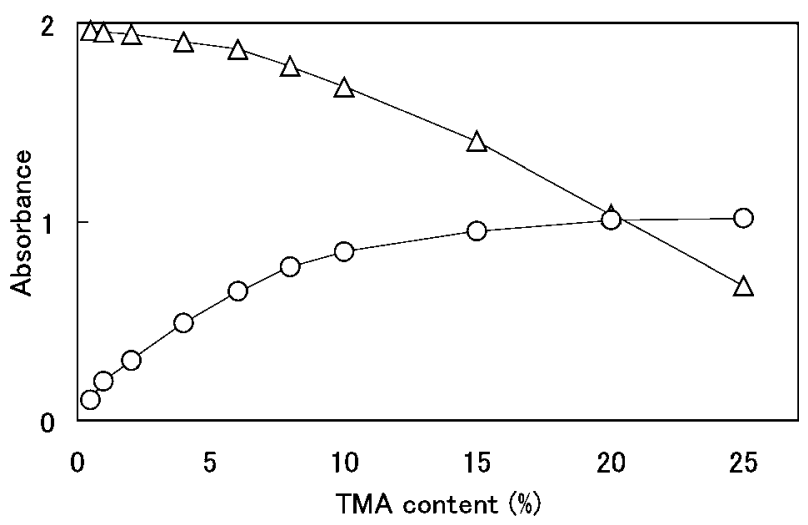

Fig. 1 Effect of tetramethylammonium hydroxide concentration on the reduction of diquat $(-\mathrm{O}$ $-)$ and paraquat $(-\triangle-)$. 
の水酸化テトラメチルアンモニウムを添加して, シ クワットに関しては $430 \mathrm{~nm}$, パラコートに関して は600 nm での吸光度の経時変化を観測した。その 結果は Fig. 2 によとめたが，ジクワットに拈いて $15 \%$ 以下の水酸化テトラメチルアンモニウムでは吸 光度が安定化するのに 1 時間以上の時間を要した が， $20 \%$ 以上の濃度であれば 20 分以降安定した吸光 度が得られた。この安定性は少なくとも2 時間は変 わらず， $\mathrm{Na}_{2} \mathrm{~S}_{2} \mathrm{O}_{4}-\mathrm{NaOH}$ 法で還元したときに生じ る吸光度の減少は観察されず, ジクワットに対して 良好な測定が可能であった。パラコートにおいて は，代表して $10 \%$ と20\%濃度のデータを示したが， 水酸化テトラメチルアンモニウムの濃度が上がると 吸光度の低下のみならず呈色の安定時間が若干減少 した.このことは，水酸化テトラメチルアンモニウ
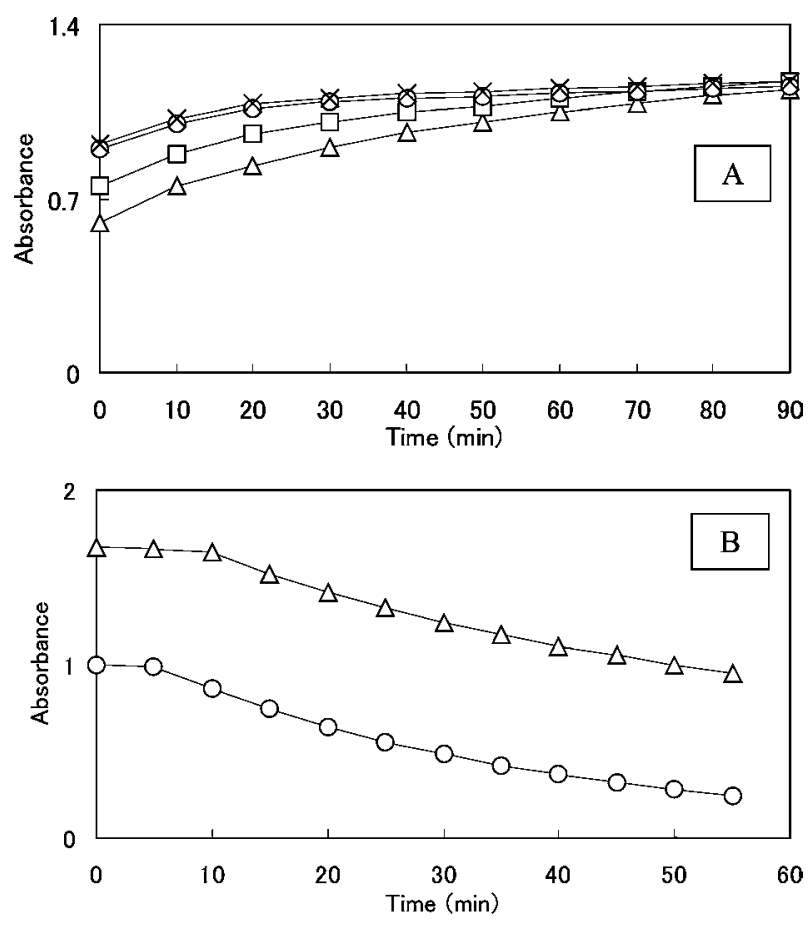

Fig. 2 Time courses of absorbance at $430 \mathrm{~nm}$ (A) after adding tetramethylammonium hydroxide and absorbance at $600 \mathrm{~nm}$ (B) after adding both tetramethylammonium hydroxide and sodium hydrosulfite to the mixed solution of diquat and paraquat. Concentrations of tetramethylammonium hydroxide in the sample were $10 \%$ ( $\triangle$ $-), 15 \%(-\square-), 20 \%(-\bigcirc-)$ and $25 \%$ ($\times-)$.
ムの過飽和が影響していると推測されたが，本法の 分析対象である混合製剂中のジクワットとパラコー トの含有率はほぼ同じであり, パラコートのみ検出 感度を上げる必要がないこと, また，ジクワットの 安定化時間をできるだけ短縮する目的から, 本法で の水酸化テトラメチルアンモニウムの濃度は $20 \%$ と した。

$40 \mathrm{ppm}$ のジクワットとパラコートの混合標準液 で測定した吸収スペクトルをFig. 3 に示した。ジ クワットは $\mathrm{Na}_{2} \mathrm{~S}_{2} \mathrm{O}_{4}-\mathrm{NaOH}$ 法で測定すると $379 \mathrm{~nm}$ と $430 \mathrm{~nm}$ の 2 つの $\lambda_{\max }$ を持つスペクトルになる が，本法で測定すると $430 \mathrm{~nm} に \lambda_{\max }$ を持つ単一の スペクトルとなり, $\lambda_{\max }$ での $\varepsilon$ は5600であり $\mathrm{Na}_{2} \mathrm{~S}_{2}$ $\mathrm{O}_{4}-\mathrm{NaOH}$ 法より吸収は強かった。 パラコートは $\mathrm{Na}_{2} \mathrm{~S}_{2} \mathrm{O}_{4}-\mathrm{NaOH}$ 法と同じスペクトル $\left(\lambda_{\max }=396\right.$ $\mathrm{nm}, 600 \mathrm{~nm}$ ) が得られ，600 nm での $\varepsilon$ は5200であ った。 また, プリグロックス $\mathrm{L}^{\circledR}$ 水で希釈した液 についても同じスペクトルが得られており, 製品中 の他成分の影響を受けないことがわかった。

ジクワットとパラコートの混合標準液を用いて，
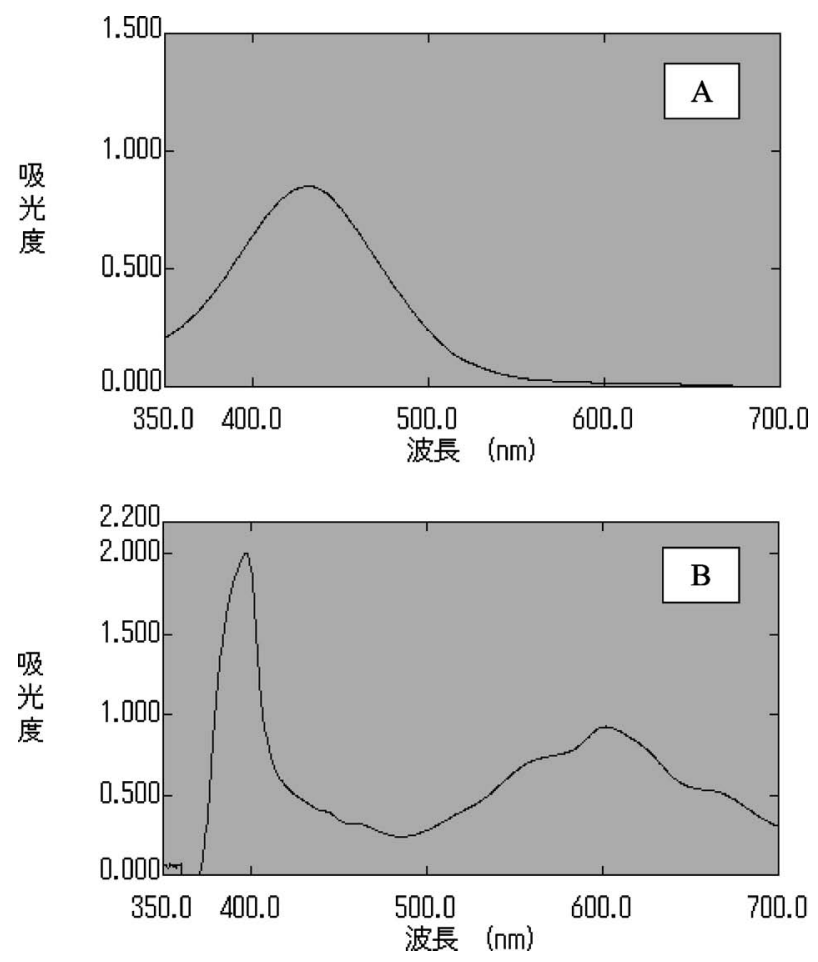

Fig. 3 Spectra of diquat (A) and paraquat (B) after reduction. 
ジクワットは $430 \mathrm{~nm}$, パラコートは $600 \mathrm{~nm}$ での吸 光度による検量線を作成したところ，いずれも 1〜 $100 \mathrm{ppm}$ の間で, ジクワット $\mathrm{y}=0.018 \mathrm{x}+0.111, \mathrm{r}^{2}$ $=0.991$, パラコート $\mathrm{y}=0.017 \mathrm{x}+0.103, \mathrm{r}^{2}=0.994$ の 良好な直線関係が得られた。作成した検量線を用い て各種濃度に調製したプリグロックス $\mathrm{L}^{\circledR}$ 中のジク ワットとパラコートの定量を行ったところ, Fig. 4. に示すとおり混合製剤濃度0.002 0.15 \%の間で定 量值と良好な相関関係にあり, この濃度間での定量 が可能であった.

目視で確認できる呈色の下限濃度はジクワットお よびパラコートいずれも, 標準液で $3 \mathrm{ppm}$ であ り，プリグロックス $\mathrm{L}^{\circledR}$ で0.005\%であった。また， ジクワットに関しては, 標準液で $5 \mathrm{ppm}$ 以上, プ リグロックス $\mathrm{L}^{\otimes} て ゙ 0.01 \%$ 以上小植ちに目視で 確認可能な呈色が得られ，20分間放置することなく スペクトル測定が可能であった.

相対標準偏差は, 胃液に $0.05 \%$ 濃度になるように プリグロックス $\mathrm{L}^{\circledR}$ を加えたものを用い，5回の繰 り返し実験により求めたところ, ジクワットは 1.53 \%, パラコートは1.84\%であった.

プリグロックス $\mathrm{L}^{\circledR}$ を服用して死亡した70歳代男 性の胃液と吐物を水で1000倍に希釈したものを本法 で分析したところ，各スペクトルはFig. 3 で示し たものと同じ特徵的なものが得られた．検量線によ り求めた定量值は, 胃液でジクワットが $25.47 \pm$ $0.23 \mathrm{ppm}$ ，パラコートが $20.34 \pm 0.63 \mathrm{ppm}$ であり, 吐物でジクワットが $14.13 \pm 0.09 \mathrm{ppm}$, パラコート

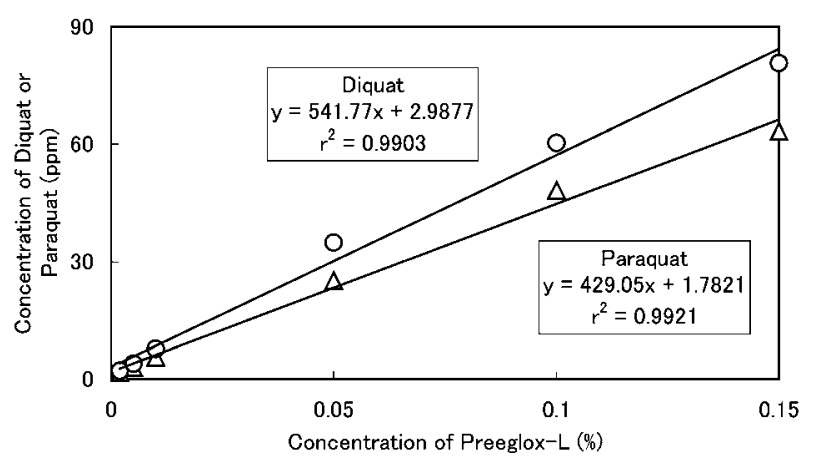

Fig. 4 Correlation of concentration between Preeglox $-\mathrm{L}^{\circledR}$ and diquat $(-\bigcirc-)$ or paraquat $(-\triangle-)$.
が9.47 $0.04 \mathrm{ppm}$ であった。これらの值から，各 資料中のプリグロックス $\mathrm{L}^{\mathbb{Q}}$ 濃度は, 胃液で約 40 \%, 吐物で約 $20 \%$ であることがわかった。 また，各 定量值をジクワット対パラコートの含有比に換算す ると, 製品表示值の 7 対 5 に近い值が得られ，この ことからも混合製剤の服用が証明された。

\section{結 語}

本法は, 分光光度計用のセル中でジクワットとパ ラコートが確認できる簡便な方法である. 我々が取 り扱う変死や毒物混入事件に抢いて，プリグロック

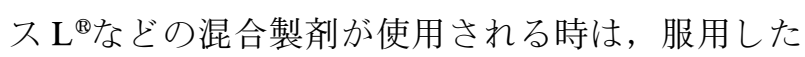
人の胃液, 飲反残し液などの中には比較的高濃度に 存在している. そのため, 中毒原因物質の判明やそ の服用の証明には，本法が非常に有効な方法と言え る.

\section{文 献}

1）内藤裕史：中毒百科. pp293-305, 南江堂, 東 京 (2001).

2) Fuke C., Ameno K., Ameno S., Kiriu T, Shinohara T., Sogo K. and Ijiri I.: A rapid, simultaneous determination of paraquat and diquat in serum and urine using second-derivative spectroscopy. J. Anal. Toxicol., 16, 214-216 (1992).

3）田山順一, 小松正孝, 土井幹雄, 大橋教良, 石 沢淳子, 水谷太郎 : 2 波長測光によるパラコー ト, ジクワット同時分析. 中毒研究, 4, 157-162 (1991).

4) Minakata K., Suzuki O., Saito S. and Harada N.: A new diquat derivative appropriate for colourimetric measurements of biological materials in the presence of paraquat. Int. J. Legal Med., 114, 1-5 (2000).

5) Ito S., Nagata T., Kudo K., Kimura K. and Imamura T.: Simultaneous determination of paraquat and diquat in human tissues by high-performance liquid chromatography. J. Chromatogr., 23, 119123 (1993).

6) Vinner E., Stievenart M., Humbert L., Mathieu D. and Lhermitte M. : Separation and quantifica- 
tion of paraquat and diquat in serum and urine by capillary electrophoresis. Biomed. Chromatogr., 15, 342-347 (2001).
7) 日本薬学会編 : 薬毒物化学試験法と注解 第 4 版. pp361-371, 南江堂, 東京 (1992). 